\title{
New Frontiers of Online Communication of Small and Medium Museums in Campania Region, Italy
}

\author{
Giuseppe Vito, Alessandra Sorrentini, Davide Di Palma, Vincenzo Raiola, Maria Tabouras \\ Parthenope University of Naples, Italy \\ Email: davide.dipalma@uniparthenope.it
}

How to cite this paper: Vito, G., Sorrentini, A., Di Palma, D., Raiola, V. and Tabouras, M. (2017) New Frontiers of Online Communication of Small and Medium Museums in Campania Region, Italy. American Journal of Industrial and Business Management, 7, 1058-1078.

https://doi.org/10.4236/ajibm.2017.79075

Received: July 5, 2017

Accepted: September 22, 2017

Published: September 25, 2017

Copyright $\odot 2017$ by authors and Scientific Research Publishing Inc. This work is licensed under the Creative Commons Attribution International License (CC BY 4.0).

http://creativecommons.org/licenses/by/4.0/

\begin{abstract}
Objectives: The purpose of this paper is to analyze the marketing relationship between small and medium museums in Campania Region and their current and potential audience. In this regard, the effectiveness of online communication proposed by these museums in relation to consumers is analyzed. A comparison is made with online communication effectiveness of large museums in order to analyse the main differences and to identify the related managerial implications. Method: The research method is based on the study of multiple cases, used in its descriptive mode. Out of 21 museums in Campania having a website administrated by the museums themselves, we selected 10 small and medium ones. Subsequently was conducted a content analysis on the aspects of the communication of Facebook pages and web sites of the 10 selected museums. Finally, 10 museums were compared with 4 large museum consortiums. Findings: The analysis has demonstrated that the communication through the Web 2.0 tools is more suited for establishing dialogic relations with the current and potential museum audiences. It has also shown that from the perspective of advanced interactivity, due to their management creativity and flexibility the communicative content of the museums under study is generally more effective than in case of larger museums having more human resources and capital at their disposal. Research limits: The main limitation of the research is that it does not detect if a performant interactive online communication is able to stimulate demand cultural. It should be noted that this objective was not the purpose of research of this paper. Originality of the study: The paper is an original and innovative work since in the literature there is no similar research conducted by other authors. Furthermore, nobody has analyzed the relationship between Facebook pages and web sites in the field of museums in the Campania region.
\end{abstract}




\section{Keywords}

Campania Region, Museum, Online Communication, Facebook, Management, Marketing

\section{Introduction}

If, as it is generally accepted, the functions of museums follow the triad "protection-study-heritage communication" [1] [2], recent multi-directional technological advances are profoundly changing the profile of museums activities, including those directly related to their organisation and management from the business perspective, analysed in Italy by scholars such as Dragoni (2005), Montella (2010), Cerquetti (2014) [3] [4] [5] $]^{1}$. In this context, progress in Information and Communication Technologies (ICT) has an impact especially on marketing communication, awaiting the opportunity for museums to embrace the relational perspective with different stakeholders by exploiting, in particular, the potential of the Web 2.0. Technological advances in the latter field allow, on the one hand, to perform better the primary function of museums- "to communicate culture to those interested without any reductionism, helping everyone to understand a new topic, potentially leading to knowledge" [6], and on the other, to expand the user audiences potentially interested in visiting the museums and establishing dialogic relations with them. Therefore, the evolution of museum communication, be it online exposure of the protected cultural heritage, or be it their own marketing activities, is shifting towards more sophisticated directions that embrace ever wider areas. In the scenario delineated above, the museums go through modernisation of their models of external communication with the public: from "one-way" mode, including that carried out through the websites, to a different one, thanks to the development of Web 2.0 and the emergence of social networks (Facebook, Twitter, etc.) and social media (YouTube, Blogger, Slideshare, etc.), a "dialogic" and interactive mode in which the recipient of the message is in turn the manufacturer of messages constituting the feedback for museums and the dissemination of experiences, feelings and opinions addressed to broad publics [7] [8] [9]. Ultimately, we witness a gradual transition from "one-way" Web communication mode, following the logic "one-to-many" (website, newsletter, etc.) to a mode characterised by a dynamic and interactive approach following "many-to-many" model, in which there is no longer a clear distinction between the sender and the receiver. Subsequently, the acceleration of Web technology offers an additional opportunity to live the "augmented reality" that will make the use of cultural heritage protected by museums easier and more effective and will enable developing more comprehensive and effective interpersonal and/or commercial arrangements [10] [11] [12]. On the demand

${ }^{1}$ It is thought here especially of prospection and discovery of archaeological remains through remote sensing and aerial photography and the availability of the Web to expose online their collections and present to current and potential audiences with richer information and content than ever before. 
side, the profound transformation of the forms of cultural communication creates new expectations of users who, through digital technology, are able to develop an effective interactive dialogue contributing to the generation of collective knowledge. "A cultural organisation, by carrying out the actions of conservation, creation and dissemination of knowledge, in fact, plays a key role of knowledge intermediation in respect to total demand, or at least the parts of demand it gets in touch with" [13]. The first ones to comply promptly with the potential of new interactive communication tools were the big museums, especially American ones, as noted by Bardon Espadas (2009) in his ranking of online visibility work (calculated not only on the basis of the use of the website but also on the social networks, primarily Facebook) of the major museums in the world [14]. In this work, the first Italian site, the Vatican Museums, appears in the eighth place. In relation to the still low-when compared with American and more developed European countries-spread of the Internet in Italian society, it is not surprising that the museum communication in Italy is still underdeveloped. Even though, at the institutional level there is a growing attention towards the planning of interventions aimed at promoting the museums heritage both nationally and locally.

\section{Study Design}

The paper focuses on the implementation of technological innovations of Web 2.0 by small and medium-sized museums through the analysis of 10 case studies of museums in Campania Region, which have the autonomy of their online communication initiatives. In fact, the selected cases are the museums that have developed their websites and Facebook pages "in house" without making use of those provided by cultural institutions, municipalities and provinces to which they belong, as most of the museums in the area have done $e^{2}$. The study unfolds through the analysis of websites according to the pattern derived from some models proposed in the literature aimed at defining the completeness, ease of use and visibility and by analysing the presence of such museums in the main social network, Facebook, according to a model developed in this paper. To complete the analysis, we propose a comparison of communicative approach of small and medium-sized museums with that the one of four largest museum centres in order to identify key management implications that characterise the differences that emerged from the comparative analysis. As a result, we arrive at a picture of the characteristics that define these communication tools in terms of their ability to build effective marketing relationships with users.

\section{Literature Review}

In respect to the competing purposes of museums together with the functions

${ }^{2}$ Most museums of Campania do not have their own websites or they are a part of the official websites of cultural institutions, municipalities and provinces they belong to. This shows a strong trend towards standardization of communication and in many cases a backward position in respect to the new paradigms of online communication, amplifying the difficulties of interaction between the potential audience (especially young people) and the museum system. 
they carry out, in the literature there are different points of view presented: the generally accepted view states that the basic functions of museums is to preserve, to study and to communicate [1] [15]. Other perspectives make a distinction between function of protection and the function of enhancement by making the protected heritage available to the public [16] [17] $]^{3}$. Ferraro (2011) identifies four functions: research and conservation, promotion and communication, support activities, networking and governance [18]. All these perspectives stress the importance of communication by museums, which have gradually changed their approach to such activities by adopting, in the last two decades, the different versions of the Web, in order to make themselves first visible to larger publics, the local ones and the tourists, and then consolidated to stimulate the creation and development of a relationship of dialogue with current and potential users with their full involvement in the relationship marketing perspective [19] [20] [21]. In fact, the actions that can be encountered in this area are closely aimed at customer loyalty building through achieving the long-term mutual satisfaction between the museum business and the consumer, focusing on the dynamism and integration between consumer behaviour and management decisions [22]. In this regard, the relationship marketing is, even in the case of museum institutions, an elective tool of the Web and, recently and more intensely, of social networks.

Below, there is a brief review of the literature concerning the most relevant themes for this paper: the evaluation of museum websites, the transition of museum communication from Web 1.0 to Web 2.0, and the use of social networks by museums. With regard to the evaluation of museum websites we refer to DiBlas et al. (2002) who introduced a method, innovative at a time (MiLEMilan-Lugano Evaluation Method) to evaluate the quality and ease of the use of museum websites [23]. The authors surveyed more than a hundred elementary terms (entries) present on the museum websites and classified them into three groups:

- The site presentation: general information about the website;

- The museum presentation: content and functions related to "physical museum";

- The virtual museum: content and functions that take advantage of the strong impact exerted by such means of communication.

In this stream of literature there are the studies investigating the accessibility and ease of the use of museum websites: Pallas e Economides (2008) introduce the MUSEF model (Museum's Sites Evaluation Framework), a guideline for the evaluation of museum websites from the users point of view [24]. The model

\footnotetext{
${ }^{3}$ In particular, in the study aimed at identifying the distribution of roles between public and private management of cultural heritage in Italy, thus implicitly museums, Dubini et al. distinguish the activities related to heritage protection from those seeking the enhancement. The protection ensures that the assets are preserved for future generations and cannot be destroyed for economic or ideological reasons through interconnected activities of research, restoration and cataloguing. Enhancement activities, such as exhibition organization and delivery of services to visitors are intended to ensure that heritage is accessible to as many visitors as possible.
} 
classifies, also in this case, a hundred elementary terms, this time grouped in six sets (families): Content, Presentation, Accessibility, Interactivity and Feedback, Online and Technical Services. For the purposes of this paper it is worth mentioning that the investigation held by the authors was extended to 210 museums in the world, which revealed that the majority of the sites require implementations related to interactivity and feedback as well as to e-services. Pallud and Straub (2014), in their study of two cases, conclude that the most important parameter for museum websites is the users' aesthetic experience of the interface and that the website structure affects the intention to visit the physical site [2]. Chiou et al. (2010) reviewed 83 scientific papers related to the website evaluation and classified the methods in three groups: Information Systems (IS), marketing, and approaches combining both [25]. The authors point out that the first studies applied mainly the IS approach while the more recent ones adopt a combined approach of the previous ones. Their study also highlights that the majority of studies reviewed translate the assessments carried out in one or more on-line rankings of site visibility. The museums transition from $1.0 \mathrm{Web}$ stage to the next Web 2.0 and in perspective to "Web-squared" is of great interest to many scholars [26] [27] [28] ${ }^{4}$. All these studies investigate the growing participatory practices for the content creation and indicate the increasing interest of the museums in the Web 2.0 technologies to reach and capture new audiences of users. In parallel to the evolution of the museums communication mode to progressively exploit the potential of Web 2.0, the attention of scholars has shifted to the use of social networks and social media related to the evaluation systems and the generation of relative ranking [11] [29] [30]. Espadas Bardon (2009) creates a ranking of museums visibility on social networks, based on the evaluation of sites, blogs, social networks and images, pointing out that on this level the American and English museums are much more ahead when compared to those of other European countries [14] $]^{5}$. Most of the studies in the specific field, touch directly or indirectly the theme of the new relationship that is established with the current and potential user of the museum by virtue of its interactive communication, placing the emphasis on the forms of participation that are to be developed that see users take a proactive role thanks to the web and various social media [31] [32]. These authors also claim that museums tend to use Web 2.0 services to enable an expansion of user communities through the integration of

\footnotetext{
"The term "Web-squared" or "augmented reality" aims to further emphasize discontinuity with the previous situation, ie Web 1.0, with the intention of indicating 'the ability to overlay information content on the Internet, making it possible to observe the surrounding reality through the diagram of a mobile device' (Solima, 2010: 31).

${ }^{5}$ The ranking obtained indicates that the Museum of Modern Art in New York and the Metropolitan Museum, also in New York, have the highest visibility on Web 2.0 sites. The world ranking is dominated by the US and British museums, while France's most important site is that of the Musée d'Orsay, in front of the Louvre. As for Spanish museums, it highlights the prominent position of the Prado over the Thyssen-Bornemisza. The reason for the dominance of English and American museums can be easily explained: in both countries, the development and spread of the Internet, also conveyed by language, has taken particularly significant size compared to other countries.
} 
the same website with other communication tools. The diffusion of interactive museum communication, especially through the channels of social integration and interactivity through social networking and tagging, can contribute, according to other scholars, to significant change of participation and modalities of participation of a large part of potential consumers [9] [33] [34]. With the adoption of Web 2.0 channels, the museum communication is therefore the protagonist of a strategic transformation into interactive mode and thrusts of actual communication networks training. In this context, many scholars devote their attention to the analysis of the "virtual" museums, where the profound transformation of the museum function, especially in terms of communication is more evident [11] [12] [13] [35] [36] [37].

Instead, this paper offers an innovative contribution to the research in order to interactive communication in traditional museums and compares the management of interactive communication of small museums with that of major museums.

\section{Methodology}

The research approach applied can be traced back to the study of multiple cases [38], which was used for the descriptive purposes. The research was conducted mainly to provide a description of the current state of online communication of medium and small museums in Campania Region that manage their websites independently and have an official Facebook page. Therefore, the study has not been designed to validate theoretical hypotheses or to move towards a 'grounded theory' that, according to the perspective of Glaser and Strauss (1967), could emerge from the study of cases [39]. Being aware that several research approaches to cases studies still have not generally accepted guidelines, we partly followed those indicated by Eisenhardt $[40]^{6}$. In the first phase of the research we formulated a broad, general research question: "Are the combined websites and Facebook pages of Campania museums, in terms of their content, able to build effective marketing relations with their current and potential publics?". The question was formulated in a broad and general way intentionally, in order to leave space for the possible emergence of more specific research questions arising from the information gathering, from data and their preliminary analyses: thus a significant margin of theoretical flexibility is allowed ${ }^{7}$. In fact, in the process of data collection and initial analysis, further and more specific research questions emerged: "Do the means of communication, websites and Facebook

${ }^{6}$ In his important contribution, the author, with the purpose of providing a roadmap to build a theory from the study of cases' and to 'put the theory building from case studies in the broader context of social research', identifies eight phases of the process. In this paper, because of its descriptive purposes, we followed the first five stages and not those established for the purpose of constructing a theory through the refinement of the assumptions and the comparison with the consistent or conflicting literature.

${ }^{7}$ What we wanted to take into account, albeit partially, was the ideal condition foreseen by Eisenhardt where the research can start "as close as possible to the ideal of no theory under consideration and no hypotheses to test" [40]. 
pages, managed in-house by medium and small museums (generally private) provide more effective content than large museums?", "Is the online communication managed by small and medium museums under study more complete than the one managed by centralised cultural institutions, provinces or municipalities?". In the second phase, the cases were selected using a non-probability sampling in order to focus on those useful for answering the research questions. The selection was difficult, which was related to the fragmentation of Campania museums in terms of size, type, ownership structure, management, service level (quality of museum environments), all factors that influence the communication activity. As for the preparation of instruments and research protocols (third phase), we identified data sources, websites and Facebook pages, of selected museums. Qualitative observations of the contents of the museums websites were complemented by counting the frequency of certain elementary entries appearing online ${ }^{8}$. In the fourth phase, the selected cases were studied extensively in order to become familiar with the information and data. Following the iterative logic, this allowed us to calibrate better the case selection, so some museums have been excluded from the first formulation of the sample and others were included. The nature of the selected cases (essentially the existing medium and small museums in Campania) did not require the verification of sample saturation (last phase of the roadmap by Eisenhardt), concluding the research process when the marginal cognitive improvements become modest. The methodology of research is schematically shown below (Figure 1).

\section{Selection of Cases}

For the selection of cases we made use of the database "Sistema Informativo Integrato" ("Integrated Information System") of MiBACT, produced by ISTAT (The National Institute for Statistics) in the period 2011-2013. The sampling was done in two stages: in the first phase we selected museums in Campania with entrance fee and with a website built and operated independently, which gave us 21 museums. In the second phase, we identified among them, those having a Facebook page built and operated independently, which gave us 10 museums. Thus, in the first phase we did not take into account the many cases using the official websites of cultural institutions, provinces or municipalities

\footnotetext{
${ }^{8}$ The observations were conducted separately by the author and three $\mathrm{PhD}$ students in order to examine the same reality from different points of view and identify emerging issues; the divergent perspectives, for example on the importance of individual terms or their placement in certain classes (families), were then discussed and unified at meetings extended to the entire workgroup.

${ }^{9}$ The Integrated Information System is the result of the collaboration established by a protocol agreement between ISTAT, Ministry of Cultural Heritage and autonomous regions and provinces. It provides overall and detailed data about all the museums, archaeological sites and monuments, state-owned and private, accessible to the public in Italy, describing how many they are, where they are located, how they are organized and how they are managed, what activities take place and what relationship they have with the public and visitors to the territory. The survey is census-like: the questionnaire must be filled by all state and non-state museums and other exhibition spaces that acquire, preserve, order and expose the public heritage and/or collections of cultural interest.
} 


\section{PHASE 1}

General research question: 'Are the combined websites and Facebook pages of Campania museums, in terms of their content, able to build effective marketing relations with their current and potential publics?'

Specific research questions emerged: 'Do the means of communication, websites and Facebook pages, managed in-house by medium and small museums (generally private) provide more effective content than large museums?', 'Is the online communication managed by small and medium museums under study more complete than the one managed by centralised cultural institutions, provinces or municipalities?'

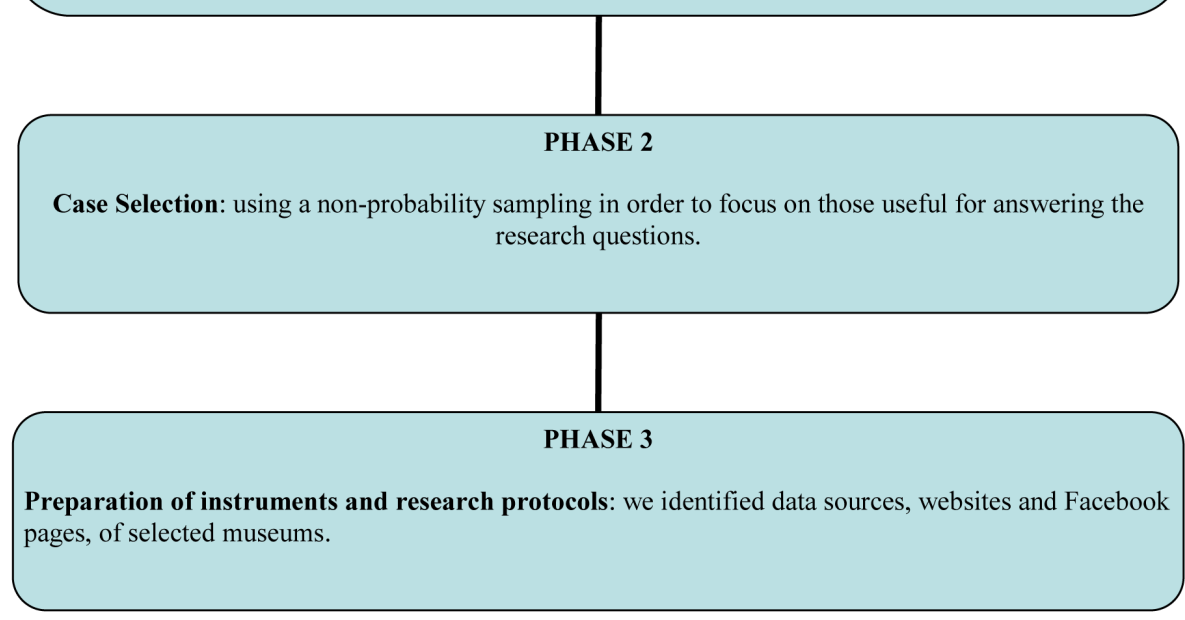

Figure 1. Scheme of methodology.

they belong to. The 21 museums selected in the first phase are shown in Table 1 with some of their characteristics relevant for the analysis. The variables in the last three columns (receipts of the sale of entry tickets; receipts of other revenues, number of visitors) in fact identify the dimensional characteristics of the analysed museums, while those of the first three columns (accountability, ownership, form of management) investigate the forms of accountability, ownership and management of museums themselves.

The ownership of the registered facilities is predominantly private except Bisaccia City Museum and Museum of Sannio (for which however there is no state responsibility); in all other cases the ownership is private or public with indirect management (Virtual Archaeological Museum). We found out a close correlation between the ownership of the facilities and the availability of independent website in all cases of non-state ownership or private management of museums.

An examination of the communication carried out by the museums through their websites has led to the identification of those having evolved tools for interactive dialogue with users (Facebook page and quality of service offered by the website) that have been included in the study. The research is thus focused on the top ten museums indicated in Table 1 . The result is a sample containing 3 museums of sacred art, 2 museums of art from Middle Ages till 1800, and $3 \mathrm{mu}$ seums of modern and contemporary art, 1 ethnographic/anthropological museum and 1 archaeological one.

For the popularity of the selected museums sites we used the Amazon Alexa 
Table 1. Campanian Museum with an independently managed website.

\begin{tabular}{|c|c|c|c|c|c|c|c|}
\hline Museum & Location & Responsibility & wnership & $\begin{array}{c}\text { Form of } \\
\text { management }\end{array}$ & $\begin{array}{l}\text { Receipts from the } \\
\text { sale of entry tickets }\end{array}$ & $\begin{array}{l}\text { Receipts from } \\
\text { other revenues }\end{array}$ & Visitors number \\
\hline San Severo Chapel & Naples & non-state & private & indirect (private) & more than a million & $\begin{array}{l}\text { No other } \\
\text { revenues }\end{array}$ & $100.001-250.000$ \\
\hline Madre Museum & Naples & non-state & private & direct & $20.001 €-50.000 €$ & $\begin{array}{l}\text { More than a } \\
\text { million }\end{array}$ & $50.001-100.000$ \\
\hline $\begin{array}{l}\text { Museum of the Treas- } \\
\text { ure of San Gennaro }\end{array}$ & Naples & non-state & private & indirect (private) & NA & $\begin{array}{l}\text { No other } \\
\text { revenues }\end{array}$ & NA \\
\hline $\begin{array}{l}\text { Pio Monte della } \\
\text { Misericordia }\end{array}$ & Naples & non-state & private & direct & $50.001 €-100.000 €$ & $\begin{array}{l}\text { No other } \\
\text { revenues }\end{array}$ & $25.001-50.000$ \\
\hline $\begin{array}{l}\text { Museum of Villa San } \\
\text { Michele }\end{array}$ & Anacapri (NA) & non-state & private & indirect (private) & $500.001 €-1$ million $€$ & 100.001 a $500.000 €$ & NA \\
\hline $\begin{array}{l}\text { Diocesan Museum of } \\
\text { Naples }\end{array}$ & Napoli & NA & NA & NA & NA & NA & NA \\
\hline PLART Foundation & (NA) & non-state & private & direct & $5.001 €-10.000 €$ & 50.001 a $100.000 €$ & $1.001-2.500$ \\
\hline CAM & Casoria (NA) & non-state & private & direct & $5.001 €-10.000 €$ & $\begin{array}{l}\text { No other } \\
\text { revenues }\end{array}$ & NA \\
\hline MAV & Ercolano (NA) & non-state & public & indirect (private) & $100.001 € 500.000 €$ & $\begin{array}{l}\text { No other } \\
\text { revenues }\end{array}$ & NA \\
\hline $\begin{array}{l}\text { Rural Culture } \\
\text { Museum M. Russo }\end{array}$ & Somma V. (NA) & non-state & private & direct & $10.001 €-20.000 €$ & $10.001 €-20.000 €$ & $1.001-2.500$ \\
\hline $\begin{array}{l}\text { Diocesan Museum of } \\
\text { Nola }\end{array}$ & Nola (NA) & non-state & private & direct & less than $1000 €$ & $10.001 €-20.000 €$ & NA \\
\hline Basilio Liverino & $\begin{array}{l}\text { Torre del Greco } \\
\qquad(\mathrm{NA})\end{array}$ & NA & NA & NA & NA & NA & NA \\
\hline Rione Terra & (NA) & NA & NA & NA & NA & NA & NA \\
\hline $\begin{array}{l}\text { Virtual Museum of } \\
\text { the Medical School of } \\
\text { Salerno }\end{array}$ & Salerno & NA & NA & NA & NA & NA & NA \\
\hline $\begin{array}{l}\text { Museum of Allied } \\
\text { Landing and Capital } \\
\text { of Salerno }\end{array}$ & Salerno & NA & NA & NA & NA & NA & NA \\
\hline $\begin{array}{l}\text { National Railway } \\
\text { Museum }\end{array}$ & Naples & NA & NA & NA & NA & NA & NA \\
\hline Sea Museum & $\begin{array}{c}\text { Pioppi-Pollica } \\
\text { (SA) }\end{array}$ & NA & NA & NA & NA & NA & NA \\
\hline $\begin{array}{l}\text { Civic Archaeological } \\
\text { Museum of Bisaccia }\end{array}$ & Avellino & non-state & public & direct & $2.501 €-5.000 €$ & $\begin{array}{l}\text { No other } \\
\text { revenues }\end{array}$ & $10.001-25.000$ \\
\hline $\begin{array}{l}\text { Archivio laboratorio } \\
\text { per le arti } \\
\text { contemporanee } \\
\text { Hermann Nitsch }\end{array}$ & Naples & non-state & private & direct & $2.501 €-5.000 €$ & $2.501 €-5.000 €$ & $1.001-2.500$ \\
\hline Sannio Museum & Benevento & non-state & public & direct & $10.001 €-20.000 €$ & $1.000 €-2.500 €$ & $10.001-25.000$ \\
\hline La Mortella Gardens & Forio (NA) & non-state & private & direct & $100.001 €-500.000 €$ & $\begin{array}{l}\text { No other } \\
\text { revenues }\end{array}$ & NA \\
\hline
\end{tabular}

Source: Author's own elaboration. 
database (24 Feb 2015) $)^{10}$, which provides a ranking of the popularity of websites worldwide. In the absence of the position occupied by the site in the Italian ranking, we used the position in the world. The museums of the selected sample are placed between the positions 1.5 and 10.1 million. To give an idea what this means, we report that the Louvre museum site occupies a position around 50.000.

\section{Evaluation of Online Communication}

\subsection{Communication via Website}

To study the museum marketing communications we examined the website contents (and in sub-paragraph Facebook pages) of the selected museums for items designed to inform, persuade and enhance relationships with current and potential visitors [41] [42]. In particular, the attention has been paid to the efforts made, especially in recent times, to activate museum organizations and improve the content of the adopted digital instruments for dialogue. The websites were assessed along the dimensions generally considered essential for an effective online communication in terms of information, persuasion and dialogue with users, namely: basic information, thematic information, basic interactivity and advanced interactivity. The basic information refers to the website's ability to provide as fully and immediately as possible all the basic information needed by potential visitors to plan their visit ("responsibility"). The thematic information ("reciprocity") is related to the information targeted at specific groups of users, particularly those aimed at the implementation of various types of promotional initiatives. These adhere to the liking of visitors of the communication system advertising museum's activities. The basic interactivity ("information sharing") is a feature that detects if the site tends to improve its capabilities through the addition of more complex information, in line with advances in technology, such as links to social networks and social media. The advanced interactivity ("increased relations") is a feature of more advanced websites and favouring communication through social networks, especially Facebook, meeting requirement of advanced interactivity. For a correct interpretation of the contents of the websites analysed, the information considered more relevant for this study has been classified into four categories: general information (15 elementary items), thematic information (6 entries), basic interactivity (18 entries) and advanced interactivity (4 entries) $)^{11}$. In particular, in order to measure the level of coverage ${ }^{10}$ Alexa Internet Inc. deals with statistics on Internet traffic and provides information about the con-
tents of each site visited: the owner, the number of pages making up the website, the number of links
pointing to the site and the frequency of updates. In relation to the popularity of the sites, Alexa
provides a global and a national ranking list. All data collected in alexa.com analyse a period of three
months and are continuously updated.
${ }^{11}$ General Information: how to reach; Google Maps; opening times and days; contacts; ticket info;
description museum; conventions; printing service; other services offered in the museum; languages;
items on the home page; identifying logo; who we are; business roles; organization chart. Thematic
information: booking online visits; project area; news and events section; download area informa-
tion; photo/video gallery; virtual tour. Basic Interactivity: Facebook link; Twitter links; YouTube
link; Google+ link; link Linkedin; Pinterest link; blog link; MySpace link; TripAdvisor link; account
newsletter; associations; site search option; donations area; sponsor/partner links; links to institu-
tional entities, associates and co-lenders; work with us; shop on-line; PayPal service. Advanced In-
teractivity: hyper-link sharing; creating personal journey; leaving comments; suggestions. 
of the information by each museum and thus the state of progress they have reached in the field of online communication, we have constructed a synthetic scheme that distinguishes the information content of the websites of each museum for thematic areas and detects the results by means of a simple system of "present" or "not present". Table 2 shows a summary of the information flow generated by the websites of the 10 surveyed museums, expressed in terms of a number of information related to the specific areas of communication identified. In fact, the presence of the latter entry is counted and added to the other items on the analysed website.

\subsection{Communication via Facebook Page}

The evaluation of the actual progress of communication activities carried out by the studied museums required the integration of the results obtained from the analysis of websites with those related to the presence of social networks, which in this contribution was limited to Facebook. In fact, it has been observed in the studied cases that a large part of interactivity objectives considered as advanced is mainly achieved through the functions performed by official Facebook page they have built and managed [13]. Therefore, the completion of the evaluation of the level of interactivity reached by each museum has been conducted through the deepening of communication carried out through Facebook. Even in this case, in order to measure the level of coverage of the information by each museum and therefore the state of progress they have reached in the field of online communication, Table 3 has been constructed where we distinguished the information content of Facebook pages of individual museums for thematic

Table 2. Communication level of websites.

\begin{tabular}{|c|c|c|c|c|}
\hline & $\begin{array}{c}\text { GENERAL } \\
\text { INFORMATION } \\
(15)\end{array}$ & $\begin{array}{c}\text { THEMATICINFORMATION } \\
(6)\end{array}$ & $\begin{array}{c}\text { BASIC INTERACTIVITY } \\
(18)\end{array}$ & $\begin{array}{c}\text { ADVANCED } \\
\text { INTERACTIVITY } \\
(4)\end{array}$ \\
\hline San Severo Chapel & 12 & 4 & 10 & 0 \\
\hline Madre Museum & 15 & 5 & 7 & 1 \\
\hline Museum of the & & & & \\
\hline $\begin{array}{l}\text { Treasure of San } \\
\text { Gennaro }\end{array}$ & 12 & 4 & 11 & 2 \\
\hline $\begin{array}{l}\text { Pio Monte della } \\
\text { Misericordia }\end{array}$ & 13 & 5 & 12 & 1 \\
\hline $\begin{array}{l}\text { Museum of Villa San } \\
\text { Michele }\end{array}$ & 13 & 4 & 8 & 1 \\
\hline $\begin{array}{l}\text { Diocesan Museum of } \\
\text { Naples }\end{array}$ & 13 & 4 & 10 & 1 \\
\hline Plart Foundation & 12 & 6 & 8 & 2 \\
\hline CAM & 13 & 4 & 11 & 0 \\
\hline $\begin{array}{l}\text { Virtual Archaeological } \\
\text { Museum }\end{array}$ & 11 & 5 & 11 & 3 \\
\hline $\begin{array}{l}\text { Rural Culture Museum } \\
\text { M. Russo }\end{array}$ & 7 & 5 & 6 & 2 \\
\hline
\end{tabular}

Source: Author's own elaboration. 
Table 3. The main contents of Facebook sites.

\begin{tabular}{|c|c|c|c|c|c|c|c|c|c|c|}
\hline & $\begin{array}{l}\text { San } \\
\text { Severo } \\
\text { Chapel }\end{array}$ & $\begin{array}{c}\text { Madre } \\
\text { Museum }\end{array}$ & $\begin{array}{c}\text { Museum of the } \\
\text { Treasure of } \\
\text { San } \\
\text { Gennaro }\end{array}$ & $\begin{array}{c}\text { Pio Monte } \\
\text { della Misericordia }\end{array}$ & $\begin{array}{c}\text { Museum } \\
\text { of Villa } \\
\text { San } \\
\text { Michele }\end{array}$ & $\begin{array}{l}\text { Diocesan } \\
\text { Museum of } \\
\text { Naples }\end{array}$ & $\begin{array}{c}\text { PLART } \\
\text { Foundation }\end{array}$ & CAM & MAV & $\begin{array}{c}\text { Rural } \\
\text { Culture } \\
\text { Museum } \\
\text { M. Russo }\end{array}$ \\
\hline No. "Like" & 17.137 & 38.002 & 635 & 3.236 & 2.704 & 12.83 & 7.981 & 5.976 & 23.516 & 1.395 \\
\hline No. visits & 2.597 & 37.574 & 2064 & 1.556 & 7.248 & 904 & 606 & 490 & 8.949 & 141 \\
\hline No. reviews & 569 & 93 & 133 & 70 & 363 & 36 & 55 & 128 & 630 & 14 \\
\hline $\begin{array}{l}\text { Average reviews } \\
\text { rating }\end{array}$ & 4,7 & 4,5 & 4,8 & 4,8 & 4,7 & 4,9 & 4,4 & 4,4 & 4,3 & 4,4 \\
\hline $\begin{array}{l}\text { Publication of } \\
\text { users' items }\end{array}$ & NA & YES & NA & NA & YES & NO & YES & YES & NA & YES \\
\hline $\begin{array}{l}\text { High response to } \\
\text { messages }\end{array}$ & YES & NA & NA & NA & NA & NA & NA & NA & YES & YES \\
\hline Address & YES & YES & YES & YES & YES & YES & YES & YES & YES & YES \\
\hline Map & YES & YES & YES & YES & NA & YES & YES & YES & YES & YES \\
\hline Contacts & YES & YES & YES & YES & NA & YES & YES & YES & YES & YES \\
\hline Opening hours & YES & YES & YES & YES & YES & YES & YES & YES & YES & YES \\
\hline $\begin{array}{l}\text { Link to official } \\
\text { website }\end{array}$ & YES & YES & YES & YES & YES & YES & YES & YES & YES & YES \\
\hline $\begin{array}{l}\text { Photo-video with } \\
\text { visitors/clients }\end{array}$ & YES & YES & YES & NA & YES & YES & YES & YES & YES & YES \\
\hline $\begin{array}{l}\text { Photo-video of } \\
\text { artwork }\end{array}$ & YES & YES & YES & YES & YES & YES & YES & YES & YES & YES \\
\hline Events section & NA & YES & YES & YES & YES & YES & NA & YES & YES & YES \\
\hline Price range & $€$ & $€$ & $€$ & $€$ & $€$ & $€$ & NA & $€$ & $€$ & $€$ \\
\hline $\begin{array}{l}\text { Trip Advisor } \\
\text { reviews }\end{array}$ & YES & NA & NA & YES & NA & YES & NA & NA & NA & NA \\
\hline $\begin{array}{l}\text { Links to other } \\
\text { social media }\end{array}$ & YES & NA & NA & NA & NA & NA & NA & NA & NA & NA \\
\hline
\end{tabular}

Source: Author's own elaboration.

areas, and note the results by the simple process based on the system "present" or "not present" already used for websites. Even if the data exhibit a high degree of variability as they are subject to rapid changes in time, this circumstance does not affect the generality of the results, aimed in particular at comparative assessment of the level of communication of the museums under study.

The rows in the table show the terms that characterise the communicative capacity of each studied museum ${ }^{12}$. In particular, it should be noted that the first 6 entries are the expression of an effective communication activity carried out through the social network reaching a high level of interactivity:

- Number of "likes": a positive feedback from the users either toward the museum or towards the contents of the Facebook page; the users thus do not represent mere visitors to the page, but the subjects that interact deciding to communicate their appreciation;

${ }^{12}$ The "NA" shows the non-availability of the item to which it refers, as evidence of a lack of information of the Facebook page analysed. 
- Number of views: number of users who decide to announce their presence by tagging a personal post (photos, videos, comments), thus helping to spread the visibility of both the museum and the content on Facebook;

- Number of reviews: considers the number of users who have decided to express their opinion about the museum through a review written and voted on a 1 to 5 scale; this communicative contribution is present on the page and is available for all other users/visitors;

- Average reviews rating: shows the average rating of all the reviews expressed by users;

- Publication of users' items: indicates whether there is the possibility for visitors to publish a communication contribution through a post (photos, videos, comments) directly on the Facebook page of the museum;

- High response to messages: indicates that users receive a reply to messages sent to the Facebook page, also quickly.

The possibility to publish items from the users on the Facebook page is an important proxy of interactive communication level that the museum is able to express. Also the high reactivity in responding to messages sent by users, and therefore potential customers/visitors, indicates the will to develop a bi-directional communication. All other items contained in Table 3, even though important to conducted survey on the official Facebook page of each museum, take up most of the information already recorded and classified during the analysis of museum websites.

\section{Results}

Table 4 summarises the informative/interactive contents of the communication carried out through the combination "website-Facebook page" of the investigated museums.

In fact, in addition to the amount of information in Table 2, we include the information found on the official Facebook page of the museum in relation to the first six entries, in Table 3. In this regard, given that the first three items of information of the Facebook page are expressed in numerical magnitudes, the same have been considered as "present" if the value was greater than the mean value $^{13}$.

The first three characteristics qualify communication carried out by the website even without the activity of advanced interactive communication and they are substantially satisfied in a fairly homogenous way for 10 museums under study. There are, however, some differences with respect to the ability of each museum to satisfy the condition of establishing closer links through the availability of a website and a Facebook page with all the necessary functions to achieve effective advanced interactive communication. In Figure 1 there are shown, in graphical summary, the data relating to the advanced interactivity of Table 4 (Figure 2). We observe firstly that the interactivity allowed by social

\footnotetext{
${ }^{13}$ The average value was calculated excluding the extremes (minor and major values).
} 
Table 4. Summary of informative/interactive content of the online communication of the studied museums.

\begin{tabular}{|c|c|c|c|c|c|}
\hline \multirow{3}{*}{ Museums } & \multicolumn{2}{|c|}{ ONE-WAY COMMUNICATION } & \multicolumn{3}{|c|}{ INTERACTIVE COMMUNICATION } \\
\hline & \multirow[t]{2}{*}{ General information [15] } & \multirow[t]{2}{*}{ Thematic information [6] } & \multirow[t]{2}{*}{ Simple interactivity [18] } & \multicolumn{2}{|c|}{ Advanced interactivity [10] } \\
\hline & & & & Website [4] & Facebook [6] \\
\hline San Severo Chapel & 12 & 4 & 10 & 0 & 4 \\
\hline Madre Museum & 15 & 5 & 7 & 1 & 4 \\
\hline $\begin{array}{l}\text { Museum of the Treasure } \\
\text { of San Gennaro }\end{array}$ & 12 & 4 & 11 & 2 & 1 \\
\hline $\begin{array}{l}\text { Pio Monte della } \\
\text { Misericordia }\end{array}$ & 13 & 5 & 12 & 1 & 1 \\
\hline $\begin{array}{l}\text { Museum of Villa San } \\
\text { Michele }\end{array}$ & 13 & 4 & 8 & 1 & 4 \\
\hline $\begin{array}{l}\text { Diocesan Museum of } \\
\text { Naples }\end{array}$ & 13 & 4 & 10 & 1 & 2 \\
\hline PLART Foundation & 12 & 6 & 8 & 2 & 2 \\
\hline CAM & 13 & 4 & 11 & 0 & 2 \\
\hline MAV & 11 & 5 & 11 & 3 & 5 \\
\hline $\begin{array}{l}\text { Rural Culture Museum } \\
\text { M. Russo }\end{array}$ & 7 & 5 & 6 & 2 & 3 \\
\hline
\end{tabular}

Source: Author's own elaboration.

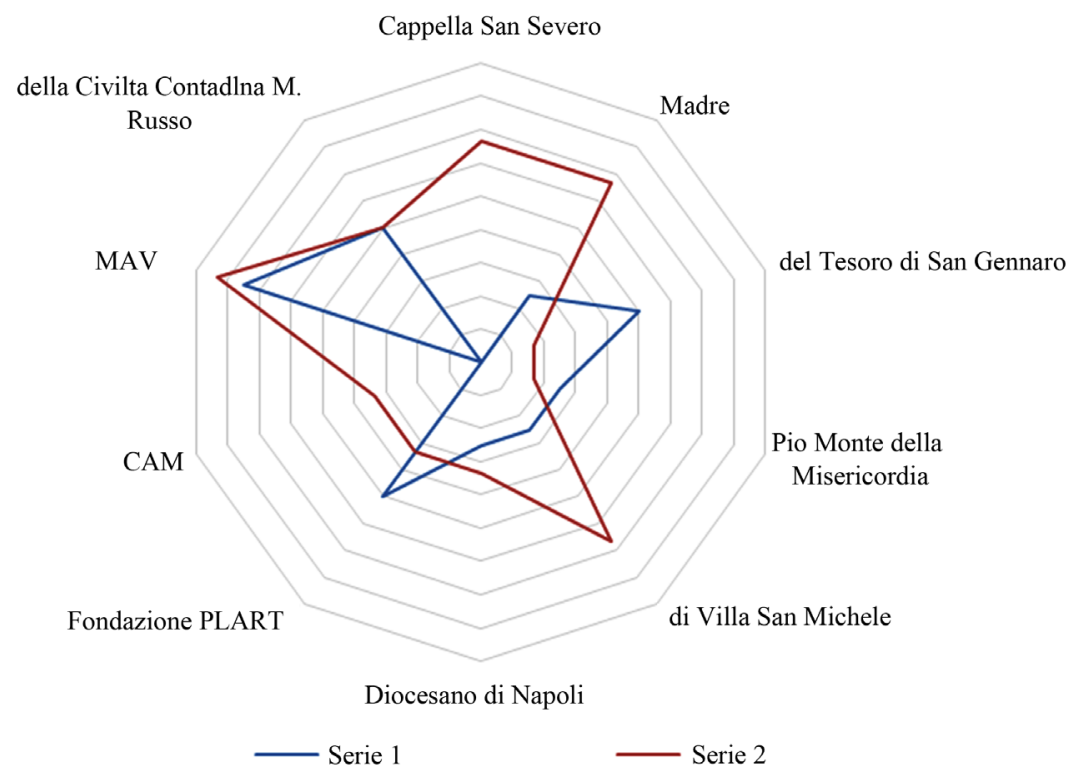

Figure 2. Compared levels of interactive communication. Series 1: website; Series 2: Facebook page-A greater distance from the center of the figure indicates an effective interactive communication on Facebook/Web Site. For example the MAV has a good interactive communication both on Facebook web site. Source: Author's own elaboration

networks is significantly greater than that of the website; and secondly that all examined museums are active in establishing online relations with users through social network. The most active museums in this respect are the Madre, Villa San Michele, and above all the MAV which is characterised by a communication strategy with the highest degree of advanced interactivity both on the website and on the Facebook page. 
The main problems are found for the CAM and, albeit less markedly, for San Severo Chapel, which do not have any elements of advanced interactivity on their websites, leaving that aspect of communication entirely to the social network.

The remaining museums, each with specific characteristics compared to others, approach this communicative form of bidirectional type on both plat- forms with one obvious propensity toward the Facebook page that, as previously specified, is more suitable for this purpose.

\section{Comparison with the Communication Strategy of Large Museums}

For the sake of completeness, we have examined four large museums and museum centres (three in Campania Region) on which we carried out the same analysis on the information and communication flow of the websites and Facebook pages, specifically we focused on (Table 5):

- Archaeological Superintendence of Pompeii Herculaneum Stabia

- National Archaeological Museum of Naples

- Capodimonte Museum;

- Vatican Museums.

The choice of these 4 museums to be compared with the initial sample was dictated by the following two considerations:

1) The three major museums in Campania have been shown, by MiBACT as the principal for the number of visitors of the region.

2) The Vatican Museums are the most visited museum in Italy (even though they belong to the State of Vatican City) according to rankings compiled by The Art Newspaper ${ }^{14}$.

The comparison aims to bring out the main differences between the communication strategy of small and medium sized museums with that of the great museum complexes, and then to analyse it from a management point of view. Below, there are the tables detecting the level of communication of the websites of four museums and the content of their Facebook pages (Table 6).

Table 5. Communication level of websites.

\begin{tabular}{|c|c|c|c|c|}
\hline & $\begin{array}{c}\text { GENERAL } \\
\text { INFORMATION } \\
(15)\end{array}$ & $\begin{array}{c}\text { THEMATIC } \\
\text { INFORMATION } \\
(6)\end{array}$ & $\begin{array}{c}\text { SIMPLE } \\
\text { INTERACTIVITY } \\
(18)\end{array}$ & $\begin{array}{c}\text { ADVANCED } \\
\text { INTERACTIVITY } \\
\text { (4) }\end{array}$ \\
\hline $\begin{array}{l}\text { Archaeological Superintendence } \\
\text { Pompeii Herculaneum Stabia }\end{array}$ & 13 & 6 & 7 & 1 \\
\hline National Archaeological Museum of Naples & 15 & 5 & 6 & 1 \\
\hline Capodimonte Museum & 13 & 5 & 2 & 1 \\
\hline Vatican Museums & 10 & 5 & 2 & 0 \\
\hline
\end{tabular}

Source: Author's own elaboration.

\footnotetext{
${ }^{14}$ The Art Newspaper is a magazine founded in 1990 with headquarters in London and New York. It provides a news service on the art world, fed by a network of 50 correspondents working in over 30 countries, with editorial offices in London, Turin, New York, Paris, Moscow, Beijing and Athens.
} 
The information resulted from the content analysis shown above, allowed the construction of the final table to determine the degree of one-way and interactive communication of the communicative approach, developed through the website and official Facebook page, which was adopted by the large museums (Table 7).

The evaluation has shown that the level of communication coming from web sites and official Facebook pages of these four museum centres, compared to the museums studied in this paper, is in line with the content expressed by the basic information and topics. At the same time, there emerge some deficiencies from the point of view of basic and advanced interactivity. For example, no website gives visitors the opportunity to express their opinion through a suggestion or leaving a comment, neither is there the opportunity to create a personalized virtual path, in contrast to the communicative approach adopted by small and medium-sized museums analysed here. Still, no Facebook profile is characterized by high response to messages sent by users, making it useless as a result, and the same refers to the presence of the option "send message".

Overall, it seems possible to affirm that the critical issue of paying less attention to the advanced interactivity aspect of communication strategies, either through the website or through the Facebook page, if the case of large museum

Table 6. The main contents of Facebook pages.

\begin{tabular}{|c|c|c|c|c|}
\hline & $\begin{array}{l}\text { 1. Archaeological Superintendence of } \\
\text { Pompeii Herculaneum Stabia }\end{array}$ & $\begin{array}{l}\text { 2. National Archaeological } \\
\text { Museum of Naples }\end{array}$ & $\begin{array}{l}\text { 3. Capodimonte } \\
\text { Museum }\end{array}$ & $\begin{array}{l}\text { 4. Vatican Museums } \\
\text { (Rome) }\end{array}$ \\
\hline No. "Like" & 20.041 & 13.98 & 43.023 & 202.419 \\
\hline No. visits & 107 & 7.183 & 12.582 & 419.393 \\
\hline No. reviews & 106 & 518 & 923 & 22.881 \\
\hline Average rating of reviews & 4,7 & 4,5 & 4,6 & 4,7 \\
\hline Publication of users' items & Yes & Yes & Yes & NA \\
\hline High response to messages & NA & NA & NA & NA \\
\hline Address & Yes & Yes & Yes & Yes \\
\hline Map & Yes & Yes & Yes & Yes \\
\hline Contacts & Yes & Yes & Yes & Yes \\
\hline Opening hours & Yes & Yes & Yes & NA \\
\hline Link to official website & Yes & Yes & Yes & Yes \\
\hline $\begin{array}{l}\text { Photo-video with } \\
\text { visitors/clients }\end{array}$ & Yes & Yes & Yes & Yes \\
\hline Photo-video of artwork & Yes & Yes & Yes & Yes \\
\hline Events section & Yes & Yes & Yes & NA \\
\hline Price range & NA & NA & NA & NA \\
\hline TripAdvisor reviews & NA & NA & NA & NA \\
\hline Links to other social media & NA & NA & NA & NA \\
\hline
\end{tabular}

Source: Author's own elaboration. 
Table 7. Summary of informative/interactive content of the online communication of 4large museums.

\begin{tabular}{|c|c|c|c|c|c|}
\hline \multirow{4}{*}{ Museums } & \multicolumn{2}{|c|}{ ONE-WAY COMMUNICATION } & \multicolumn{3}{|c|}{ INTERACTIVE COMMUNICATION } \\
\hline & \multirow{3}{*}{$\begin{array}{c}\text { General information } \\
{[15]}\end{array}$} & \multirow{3}{*}{$\begin{array}{c}\text { Thematic } \\
\text { information [6] }\end{array}$} & \multirow{3}{*}{$\begin{array}{l}\text { Simple interactivity } \\
{[18]}\end{array}$} & \multicolumn{2}{|c|}{ Advanced interactivity } \\
\hline & & & & \multicolumn{2}{|c|}{-10} \\
\hline & & & & Website [4] & Facebook [6] \\
\hline $\begin{array}{l}\text { Archaeological Superintendence } \\
\text { Pompeii Herculaneum Stabia }\end{array}$ & 13 & 6 & 7 & 1 & 2 \\
\hline $\begin{array}{l}\text { National Archaeological Museum } \\
\text { of Naples }\end{array}$ & 15 & 5 & 6 & 1 & 2 \\
\hline Capodimonte Museum & 13 & 5 & 2 & 1 & 5 \\
\hline Vatican Museums & 10 & 5 & 2 & 0 & 4 \\
\hline
\end{tabular}

Source: Author's own elaboration.

complexes analysed comparatively with the sample of the 10 selected museums. The conducted analysis revealed a comprehensive picture of the current state of online communication of medium and small museums (mostly private) of Campania, and a comparison with the communicative approach adopted by major museum institutions. Although the selected case studies essentially represent the universe of regional museums that meet the established inclusion criteria, on the other hand, they represent a sample of medium and small Italian museums, so the results can form the basis for further research.

\section{Conclusions and Directions for Future Research}

The paper has demonstrated that interactivity enabled by Web 2.0 tools, in particular the social network Facebook, enhances and completes the communication carried out through the museum website, now considered traditional, allowing the active participation of users and laying the foundation for building effective marketing relationship between museums and their current and potential audiences. More specifically, the contribution shows that all the media, consisting of the websites and the Facebook pages managed in-house by museums in medium and small private-generally, provide the relational marketing contents far more effectively than in case of large museum enterprises, and therefore, greater attractiveness to visitors. Moreover, self-managed on-line communication is generally more comprehensive than the one handled centrally by cultural institutions, provinces or municipalities where museums belong.

The development of on-line media in the museum environment, therefore, leads us to rethink the relationship between the museum and the user, who becomes the secondary content producer providing feedback for the museum and for the large audience of interested internet users, spread almost in real time. This gives rise to a kind of collective user that is able to influence the consumption behaviour of potential users. Above all, the user is the holder of a collective thought that according to sociological theory of "wisdom of crowds", is able to 
provide equally (or even more) adequate and effective response to a question than the experts [43] [44].

The set of measurements shows a significantly advanced reality in regard to relational marketing allowing to conclude, in line with other authors, that as far as large museums can count on extensive human and capital resources, the autonomy and flexibility of medium and small institutions can be achieved through creativity and innovation [45].

In this regard, the greater development of interactive communication of small and medium museums, compared to those considered as large, is the main instrument allowing a reduction of the structural and economic-financial gap existing between these two categories. In fact, any other management strategy, including the most commonly used at the enterprise level, which intends to bring a small museum "popularity" and the features a large museum complex, such as those analysed, would require a considerable economic effort. In contract, choosing to invest in a communicative approach characterized by heavy use of a social network like Facebook with a high media coverage involves almost zero costs [46] [47] [48].

An interesting starting point for future research might be the possibility to measure in economic terms the reduction of the gap generated by a different communication approach that is based primarily on a greater degree of advanced interactivity by small and medium sized museums. Among further research directions arising from the approach taken in the analysis and critical reflection of the obtained results, we would indicate the opportunity to conduct longitudinal analyses on the effect that online communication can have on the progress of visitors' frequency at the physical sites of museums.

The current main obstacle to pursuing such research is in the data: the lack of time series of the development of museums online communication and, in perspective, the dynamism that characterizes the communication itself, mainly as the relentless effect and rapid evolution of information technology and telecommunications. Furthermore, the possibility to define, through specific studies, the levels of completeness, ease of use and visibility of websites and social networks pages of small and medium Italian museums or other regions, requires comparison with one or more benchmarks, which in this study are represented by the Madre Museum and PLART Foundation.

\section{References}

[1] Weil, E.S. (2004) Rethinking the Museum: An Emerging New Paradigm. In: A.G., Ed., Reinventing the Museum: Historical and Contemporary Perspectives on the Paradigm Shift, AltaMira Press, Lanhman.

[2] Pallud, J. and Straub, D.W. (2014) Effective Website Design for Experience-Influenced Environments: The Case of High Culture Museums. Information \& Management, 51, 359-373.

[3] Dragoni, P. (2005) Antimarketing dei musei italiani? Sinergie, 68, 55-74.

[4] Montella, M. (2010) Le scienze aziendali per la valorizzazione del capitale culturale storico. Il capitale culturale, 1, 11-22. 
[5] Cerquetti, M. (2014) Marketing museale e creazione di valore: Strategie per l'innovazione dei musei italiani, Franco Angeli, Milano.

[6] Vercelloni, V. (2005) Museo e comunicazione culturale. In: Lugli, A., Pinna, G. and Vercelloni, V., Eds., Tre idee di museo, Jaca Book, Milano, 163-191.

[7] Sibilio Parri, B. (2004) Quale bilancio per ilmuseo? In: Sibilio Parri, B., Ed., Misurare e comunicare $i$ risultati. L'accountability del museo, Franco Angeli, Milano.

[8] Pisu, C. (2012) I musei italiani nei social networks: Relazione preliminare sui risultati dell'indagine promossa dall'Associazione Nazionale Piccoli Musei.

[9] Sibilio Parri, B. and Manetti, G. (2014) Il dialogo fra musei e stakeholders tramite Internet: Il caso delle Soprintendenze Speciali per il patrimonio storico, artistico ed etnoantropologico e per i Poli museali. Il capitale culturale, 9, 123-153.

[10] Wojciechowski, R., Walczak, K., White, M. and Cellary, W. (2004) Building Virtual and Augmented Reality Museum Exhibitions. Proceedings of the 9 th International Conference on $3 D$ Web Technology. https://doi.org/10.1145/985040.985060

[11] Feliciati, P. (2012) Ask the users, il valore aggiunto della valutazione dei sistemi informativi culturali on line coinvolgendo gli utenti: Il caso del progetto Una Città per gli Archivi. Il capitale culturale, 5, 129-144.

[12] Bonacini, E. (2014) La realtà aumentata e le app culturali in Italia: Storie da un matrimonio in mobilità. Il capitale culturale, 9, 89-121.

[13] Solima, L. (2010) Social Network: Verso un nuovo paradigma per la valorizzazione della domanda culturale. Sinergie, 28, 47-74.

[14] Espadas Bardon, J. (2009) Museums Web 2.0 Ranking (Jun. 2009). T.-B. C. Foundation.

[15] Poulot, D. (2005) Musée et muséologie. Édition la Découverte, Paris.

[16] Mclean, F. (1995) A Marketing Revolution in Museums? Journal of Marketing Management, 11, 601-616. https://doi.org/10.1080/0267257X.1995.9964370

[17] Dubini, P., Leone, L. and Forti, L. (2012) Role Distribution in Public-Private Partnerships: The Case of Heritage Management in Italy. International Studies of Management \& Organization, 42, 57-75. https://doi.org/10.2753/IMO0020-8825420204

[18] Ferraro, V. (2011) Restyling Museum Role and Activities: European Best Practices towards a New Strategic Fit. Il capitale culturale, 2, 133-177.

[19] Ferrero, G. (1993) Il marketing relazionale. L'approccio delle scuole nordiche, Lint Editoriale, Trieste.

[20] Gummesson, E. and Costabile, M. (2006) Marketing relazionale: Gestione del marketing nei network di relazioni, Hoepli, Milano.

[21] Solima, L. and Minguzzi, A. (2015) Innovare il rapporto tra musei, visitatori ed utenti attraverso le relazioni digitali. Economia e diritto del terziario.

[22] Grönroos, C. (1994) From Marketing Mix to Relationship Marketing. Management Decision, 32, 4-20. https://doi.org/10.1108/00251749410054774

[23] Di Blas, N., Guermand, M.P., Orsini, C. and Paolini, P. (2002) Evaluating the Features of Museum Websites: (The Bologna Report). Museums and the Web 2002, Boston.

[24] Pallas, J. and Economides, A.A. (2008) Evaluation of Art Museums' Web Sites Worldwide. Information Services \& Use, 28, 45-57. https://doi.org/10.3233/ISU-2008-0554

[25] Chiou, W.C., Lin, C.C. and Perng, C. (2010) A Strategic Framework for Website Evaluation Based on a Review of the Literature from 1995-2006. Information \& Management, 47, 282-290. 
[26] Srinivasan, R., Boast, R., Furner, J. and Becvar, K.M. (2009) Digital Museums and Diverse Cultural Knowledge: Moving Past the Traditional Catalog. Information Society, 25, 265-278. https://doi.org/10.1080/01972240903028714

[27] Wang, Y., Stash, N., Sambeek, R., Schuurmans, Y., Aroyo, L., Schreiber, G. and Gorgels, P. (2009) Cultivating Personalized Museum Tours On-Line and On-Site. Interdisciplinary Science Reviews, 34, 139-153. https://doi.org/10.1179/174327909X441072

[28] Solima, L. (2010) Museum Unlock. Soluzioni digitali per musei reali, dal Qrcode alla Internet of Things. Heritage, management e impresa: Quali sinergie?

[29] Hazan, S. (2011) The Museum in the Palm of Your Hand: Presenting the Israel Museum through ICT. Il capitale culturale, 3, 11-23.

[30] Feliciati, P. (2013) The Web Communication of the Archaeological Research on Field: Some Remarks. Il Capitale Culturale. Studies on the Value of Cultural Heritage, 7, 165-177.

[31] Arends, M., Goldfarb, D., Merkl, D. and Weingartner, M. (2009) Interaction with Art Museums on the Web. IADIS Int I Conference WWWIInternet, Rome.

[32] Gabellone, F. (2015) Integrated Technologies for Museum Communication and Interactive Apps in the PON DiCet Project. International Conference on Augmented and Virtual Reality, Springer International Publishing, Berlin, 3-16.

[33] Jin-Tsann, Y. and Chyong-Ling, L. (2005) Museum Marketing and Strategy: Directors' Perception and Belief. Journal of American Academy of Business, Cambridge, 6, 279-284.

[34] Gordin, V. and Dedova, M. (2014) Cultural Innovations and Consumer Behaviour: The Case of Museum Night. International Journal of Management Cases, 16, 32-40.

[35] Bowen, J. (2000) The Virtual Museum. Museum International, 52, 4-7. https://doi.org/10.1111/1468-0033.00236

[36] De Man, A. and Oliveira, C. (2016) A Stakeholder Perspective on Heritage Branding and Digital Communication. In: Tourism and Culture in the Age of Innovation, Springer International Publishing, Berlin, 447-455. https://doi.org/10.1007/978-3-319-27528-4_30

[37] Hume, M. and Mills, M. (2011) Building the Sustainable I Museum: Is the Virtual Museum Leaving Our Museums Virtually Empty? International Journal of Nonprofit \& Voluntary Sector Marketing, 16, 275-289. https://doi.org/10.1002/nvsm.425

[38] Yin, R.K. (2003) Case Study Research: Design and Methods. 3rd Edition, Sage, London.

[39] Glaser, B.G. and Strauss, A.L. (1967) The Discovery of Grounded Theory: Strategies for Qualitative Research. Aldine Pub, Chicago.

[40] Eisenhardt, K.M. (1989) Building Theories from Case Study Research. Academy of Management Review, 14, 532-550.

[41] Kotler, P. (2007) Marketing Management. Pearson, London.

[42] Prunesti, A. (2013) Social media e comunicazione di marketing. Presidiare la Rete, costruire relazioni e acquisire clienti con gli strumenti del Web 2.0. Franco Angeli, Milano.

[43] Galton, F. (1907) Vox Populi. Nature, 75, 450-451. https://doi.org/10.1038/075450a0

[44] Surowiecki, J. (2004) The Wisdom of Crowds: Why the Many Are Smarter than the Few and How Collective Wisdom Shapes Business, Economies, Societies, and $\mathrm{Na}$ tions. Doubleday, New York. 
[45] Mcnichol, T. (2005) Creative Marketing Strategies in Small Museums: Up Close and Innovative. International Journal of Nonprofit \& Voluntary Sector Marketing, 10, 239-247. https://doi.org/10.1002/nvsm.28

[46] Conti, L. and Carriero, C. (2014) Facebook Marketing: Comunicare e vendere con il social network. Hoepli Editore, No. 1.

[47] Pascucci, F. (2013) Strategie di marketing online per il vantaggio competitivo aziendale. Società Editrice Esculapio. https://doi.org/10.15651/978-88-748-8597-8

[48] Sorrentini, A. (2016) La comunicazione on-line dei piccoli e medi musei della Campania. Heritage, management e impresa: Quali sinergie?

Submit or recommend next manuscript to SCIRP and we will provide best service for you:

Accepting pre-submission inquiries through Email, Facebook, LinkedIn, Twitter, etc. A wide selection of journals (inclusive of 9 subjects, more than 200 journals)

Providing 24-hour high-quality service

User-friendly online submission system

Fair and swift peer-review system

Efficient typesetting and proofreading procedure

Display of the result of downloads and visits, as well as the number of cited articles

Maximum dissemination of your research work

Submit your manuscript at: http://papersubmission.scirp.org/

Or contact ajibm@scirp.org 